\title{
PARTISIPASI DAN PEMBERDAYAAN MASYARAKAT DALAM PENGELOLAAN DAYA TARIK WISATA "RICE TERRACE" CEKING, GIANYAR, BALI
}

\author{
Fatrisia Yulianie \\ Email: yulianie_f@yahoo.com
}

\begin{abstract}
This article analyzes about the participation and community empowerment in the management of unique and beautiful tourist attraction of rice terrace in Ceking Village, Gianyar Regency. It also discuses tourists' opinion to the tourist attraction of Ceking. The theories used in this research are the theory of participation and community management theory. Data were collected through observation, interviews, documentation, and questionnaires. The sampling techniques used were purposive and accidental sampling. Data were analyzed by using descriptive qualitative analysis to give an overview of community empowerment in the management of tourist attraction in the Village of Ceking of Tegallalang, the Gianyar Regency. The finding shows that people around the tourist attraction of Ceking have participated in the development of the tourist attraction. However, the community empowerment of Ceking tourist attraction has not been performed optimally yet, because around the tourist attraction, there are two large communities, namely the villages of Tegallalang and Kedisan. The Kedisan community, as the owner of the rice terrace, has not been optimally empowered and involved in the management and development. Tourists visiting Ceking considered it an interesting tourist attraction to visit, but expressed that the infrastructure and the tourist facilities on the attraction are very poor and need improvement.
\end{abstract}

Keywords: Ceking rice terraces, community participation, community empowerment, tourist attraction management.

\section{Pendahuluan}

Pemerataan pembangunan pariwisata di Bali khususnya di Kabupaten Gianyar dapat dilakukan dengan pemanfaatan potensi desa sebagai daya tarik wisata. Pengembangan pariwisata dapat meningkatkan keterlibatan masyarakat desa, dan bermuara pada peningkatan kesejahteraannya. Pengembangan pariwisata diharapkan mempercepat upaya pemerintah dalam pengentasan masyarakat miskin. Oleh karena itu, perlu adanya 
pemberdayaan masyarakat lokal untuk melaksanakan pengembangan dan pengelolaan sebuah daya tarik wisata.

Menurut Payne (dalam Pitana, 2011:2), pemberdayaan adalah proses untuk membantu masyarakat mendapatkan daya, kekuatan, atau kemampuan untuk mengambil keputusan dan tindakan, termasuk mengurangi kendala pribadi dan sosial di dalam mengambil keputusan dan tindakan tersebut. Pemberdayaan masyarakat dalam kegiatan pariwisata dapat diterapkan berbentuk pengembangan pariwisata berbasis kerakyatan dan dikelola dengan manajemen komunitas yaitu masyarakat setempat.

Pariwisata berbasis kerakyatan menitikberatkan pada keseimbangan dan keharmonisan di antara lingkungan hidup, sumber daya alam dan sumber daya manusia serta pengunjung atau wisatawan yang dijiwai dengan pemanfaatan kearifan-kearifan lokal sebagai daya tarik wisatanya, memeliharalingkungan tetaplestari, mengkonsumsi hasil pertanian setempat serta mencintai budaya, adat istiadat masyarakat setempat. Partisipasi masyarakat dalam pembangunan pariwisata diartikan sebagai keterlibatan secara aktif dalam setiap proses pengembangan dari industri pariwisata, yaitu mulai dari perencanaan, penentuan rancangan, pelaksanaan, sampai dengan pengawasan dan pengevaluasian, dan penikmatan hasilnya (Pitana, 1999:78).

Dalam pengoperasian pengelolaan manajemen komunitas, mengacu kepada tiga alasan mendasar yang dikemukakan oleh Korten (1986:5), yaitu local variety, maksudnya variasi kehidupan masyarakat lokal ataupun kehidupan yang berbeda menuntut sistem pengelolaan yang berbeda, tidak dapat diberikan perlakuan sama dan masyarakat lokallah yang paling akrab dengan situasinya; local resource, artinya sumber daya secara tradisional dikuasai dan dikelola oleh masyarakat setempat; local accountability atau tanggungjawab lokal, yaitu pengelolaan yang dilakukan oleh masyarakat setempat biasanya lebih bertanggungjawab karena kegiatan yang dilakukan secara langsung akan mempengaruhi hidupnya.

Desa Tegallalang, Kabupaten Gianyar, memiliki potensi wisata baik alam maupun budaya. Desa ini telah menjadi daya tarik wisata yang didukung dengan sarana dan prasarana pariwisata yang memadai. Prasarana jalan, telekomunikasi, sarana akomodasi, restoran, artshop, galeri telah berkembang di wilayah Desa Tegallalang. Hal tersebut telah memudahkan wisatawan yang berkunjung untuk menikmati keindahan alam dan budaya yang ada serta memenuhi kebutuhan lainnya. Potensi wisata yang paling menonjol di Desa Tegallalang yaitu potensi alam khususnya pertanian. Potensi pertanian yang sangat dikenal dan menjadi daya tarik utama bagi masyarakat berupa lahan pertanian berundak-undak yang dikenal dengan Ceking rice terrace. Ceking rice terrace adalah daerah yang menggunakan sistem pertanian terasering atau bentuk area persawahan yang berundak- 




FATRISIA YULIANIE

Foto 1. Teras sawah di Ceking yang indah dan unik menjadi daya tarik wisata.

undak pada daerah miring atau lereng bukit (Foto 1).

Lokasi daya tarik wisata Ceking yang berada di wilayah perbatasan antara desa memerlukan kearifan dan kebersamaan dalam pengelolaan agar tidak terjadikonflikkepentingan.Terasering Cekingsebagaidayatarikutamaberada di wilayah Desa Kedisan, dan tempat terbaik untuk melihat pemandangan terasering berada di tebing sisi barat yakni wilayah Desa Tegallalang. 
Kondisi ini akan menjadi sebuah tantangan khususnya dalam pengelolaan dan pengembangan daya tarik wisata yang berbasiskan masyarakat, perlu adanya partisipasi yang aktif dan pemberdayaan masyarakat di dalamnya. Artikel ini membahas bentuk partisipasi masyarakat dalam pengembangan daya tarik wisata Ceking; pemberdayaan masyarakat dalam pengelolaan dan pengembangan daya tarik wisata Ceking; dan tanggapan wisatawan terhadap daya tarik wisata Ceking.

\section{Teori dan Metode}

Teori yang digunakan dalam artikel ini adalah teori partisipasi dan teori manajemen komunitas. Mikkelsen (2003:64) mendefinisikan partisipasi sebagai proses yang aktif, yang mengandung arti bahwa orang atau kelompok yang terkait, mengambil inisiatif dan menggunakan kebebasannya untuk melakukan hal itu. Partisipasi juga diartikan sebagai keterlibatan masyarakat dalam pembangunan diri, kehidupan dan lingkungan mereka. Dalam

Pendekatan-pendekatan dalam partisipasi yaitu: Partisipasi pasif, suatu pendekatan yang menyatakan "kami lebih tahu apa yang baik bagimu" ini merupakan komunikasi satu arah, dimana informasi diberikan pada masyarakat untuk menerimanya. Partisipasi aktif, merupakan pendekatan pelatihan dan kunjungan dimana dialog dan komunikasi dua arah keterikatan, suatu pendekatan "kontrak tugas yang dibayar" yang berpandangan bila anda melakukan ini, maka proyek akan melakukan itu. Partisipasi atas permintaan setempat, merupakan pendekatan yang didorong oleh permintaan, dan dilakukan untuk menjawab kebutuhan yang dinyatakan oleh masyarakat, bukan kebutuhan perancang (Mikkelsen, 2003:65-70).

Berdasarkan sistem dan mekanisme partisipasi, Cohen dan Uphoff (1977:58), membedakan partisipasi menjadi empat jenis yaitu: participation in decision making, participation in implementation, participation in benefits, participation in evaluation. Participation in decision making adalah partisipasi masyarakat dalam proses pembuatan keputusan dan kebijakan organisasi. Partisipasi dalam bentuk ini berupa pemberian kesempatan kepada masyarakat dalam mengemukakan pendapatnya untuk menilai suatu rencana atau program yang akan diterapkan. Masyarakat juga diberikan kesempatan untuk menilai suatu keputusan atau kebijakan yang sedang berjalan. Participation in implementation adalah partisipasi atau keikutsertaan masyarakat dalam kegiatan operasional pembangunan berdasarkan program yang telah ditetapkan. Participation in benefits adalah partisipasi masyarakat dalam menikmati atau memanfaatkan hasilhasil pembangunan yang dicapai dalam pelaksanaan pembangunan. Jenis partisipasi yang terakhir yaitu participation in evaluation adalah partisipasi masyarakat dalam bentuk keikutsertaan menilai serta mengawasi kegiatan pembangunan serta hasil-hasilnya. 
Teori partisipasi digunakan untuk menganalisis karakteristik masyarakat dan partisipasinya dalam pengelolaan daya tarik wisata Ceking baik partisipasi dalam pembuatan keputusan, partisipasi dalam melaksanakan hasil keputusan, partisipasi dalam memperoleh manfaat, maupun partisipasi dalam evaluasi.

Teori yang digunakan selanjutnya adalah teori manajemen komunitas. Pembangunan berbasis komunitas merupakan paradigma alternatif terhadap kegagalan paradigma birokratis yang dianggap menciptakan ketergantungan masyarakat perdesaan terhadap birokrasi. Atas dasar itulah, Korten (1986), memperkenalkan paradigma kerakyatan (people centered development). Korten mengungkapkan bahwa pembangunan kerakyatan adalah sebagai produk dan prakarsa kreatif masyarakat dengan tujuan untuk mewujudkan pemberdayaan. Moeljarto (1993:26), pengelolaan sumber daya yang bertumpu pada komunitas merupakan pendekatan yang dikemukakan oleh David Korten. Teori manajemen komunitas digunakan untuk menganalisis pemberdayaan masyarakat dalam pengelolaan dan pengembangan di daya tarik wisata Ceking.

Artikel ini menggunakan metode deskriptif kualitatif yang berusaha mendeskripsikan fenomena atau hubungan antar fenomena yang diteliti dengan sistematis, faktual, dan akurat (Kusmayadi, 2000:29). Jenis data yang dikumpulkan adalah data kualitatif yang berupa kalimat atau uraian dan data kuantitatif yang berupa angka-angka. Sumber data yang digunakan adalah sumber data primer dan data sekunder. Sumber data primer yaitu yang bersumber langsung dari informan. Sedangkan data sekunder yaitu yang bersumber dari pihak lain atau bukan dari sumber pertama yang berkaitan dengan penelitian ini. Data yang diperoleh melalui observasi, wawancara mendalam, studi kepustakaan, studi dokumentasi dan angket dianalisis secara deskriptif kualitatif. Penentuan informan dilakukan dengan cara purposive sampling dan untuk responden wisatawan dilakukan dengan teknik accidental sampling.

\section{Kedatangan Wisatawan dan Pendapatan}

Kunjungan wisatawan ke Ceking merupakan sumber pendapatan Badan Pengelola Objek Wisata Ceking (BPOWC) dan dana itu didistribusikan sesuai kesepakatan. Kunjungan wisatawan dari 13 bulan terakhir yaitu dari bulan Januari 2014 sampai dengan Januari 2015 ke daya tarik wisata Ceking berdasarkan data yang diperoleh dari BPOWC menunjukkan pasang surut namun masih berjumlah di atas 20.000 wisatawan. Jumlah kunjungan wisatawan tertinggi terdapat pada bulan Agustus 30.800 dan kunjungan wisatawan terendah pada bulan April sebesar 22.500. Jumlah kunjungan wisatawan tersebut dapat disajikan seperti Tabel 1. Hasil wawancara yang dilakukan dengan BPOWC dan pengusaha pariwisata setempat, rata-rata 


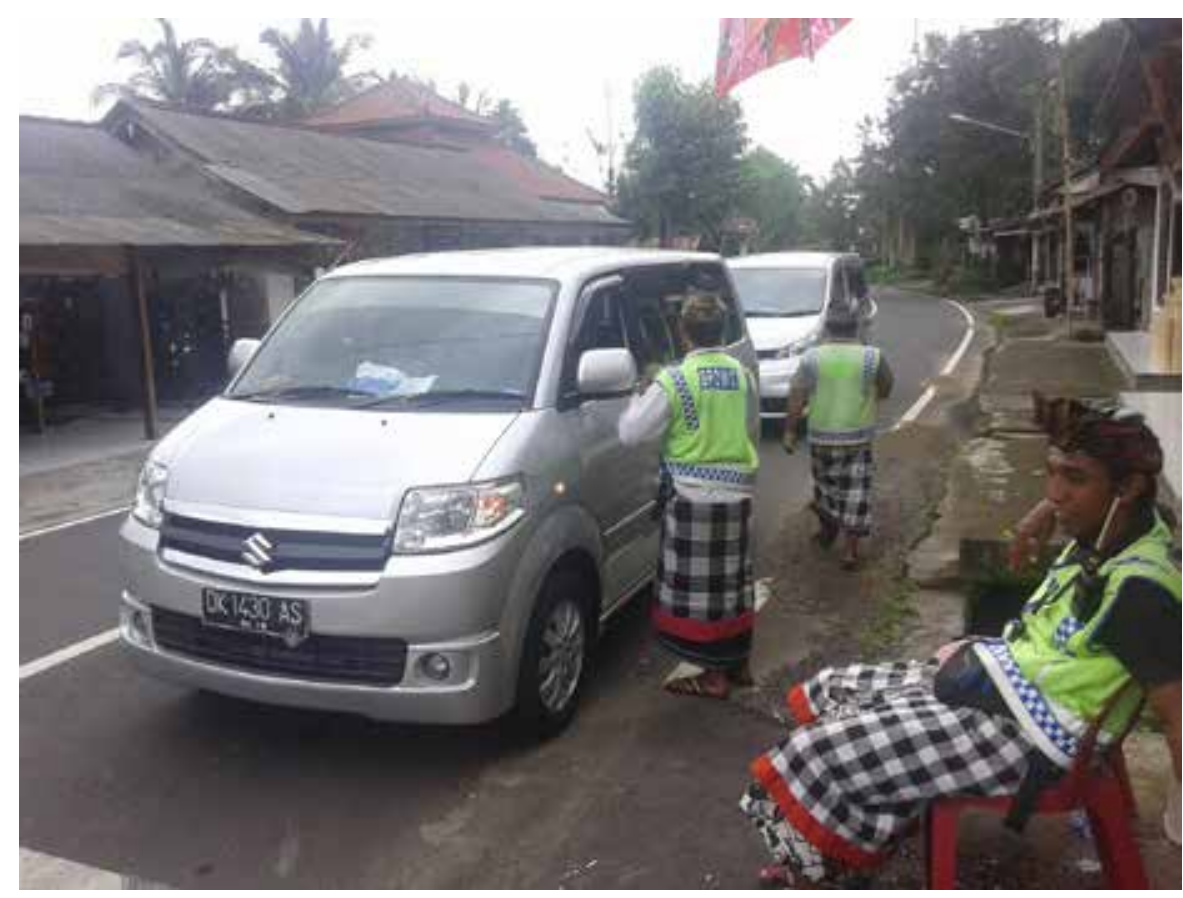

FATRISIA YULIANIE

Foto 2. Anggota badan pengelola mengatur parkir di daya tarik wisata Ceking.

kedatangan wisatawan ke daya tarik wisata Ceking meningkat pada saat musim liburan yaitu pada bulan Juli, Agustus, pertengahan bulan Desember, dan bulan Januari (Foto 2).

Tabel 1 Jumlah Kunjungan ke Daya Tarik Wisata Ceking Januari 2014 -2015

\begin{tabular}{clrc}
\hline No. & \multicolumn{1}{c}{ Bulan } & Jumlah & Pertumbuhan (\%) \\
\hline 1. & Januari 2014 & 23.000 & - \\
2. & Februari 2014 & 23.500 & 2,17 \\
3. & Maret 2014 & 23.600 & 0,43 \\
4. & April 2014 & 22.500 & $-4,66$ \\
5. & Mei 2014 & 24.100 & 7,11 \\
6. Juni 2014 & 24.175 & 0,31 \\
7. & Juli 2014 & 29.200 & 20,79 \\
8. & Agustus 2014 & 30.800 & 5,48 \\
9. & September 2014 & 29.100 & $-5,52$ \\
10. & Oktober 2014 & 27.400 & $-5,84$ \\
11. & November 2014 & 23.700 & $-13,50$ \\
12. & Desember 2014 & 24.300 & 2,53 \\
13. Januari 2015 & 25.000 & 2,88 \\
Kunjungan dan rata-rata pertumbuhan & 330.375 & $1,02 \%$ \\
\hline
\end{tabular}

Sumber: BPOWC 2015 
Jumlah kunjungan menentukan pendapatan. Tahun 2014, total pendapatan mencapai Rp 1,5 milyar (Tabel 2). Pendapatan ini didistribusikan ke dalam berbagai pihak untuk biaya pengelolaan. Pembagian tersebut meliputi untukbiaya operasional sebesar 32,34\%; Desa Pakraman Tegallalang sebesar 35\%; investasi 30 \% dan askes 2,66 \%. Pendapatan yang digunakan untuk biaya operasional sebagian didistribusikan kepada masyarakat Desa Kedisan selaku pemilik lahan seperti untuk sumbangan Piodalan di Pura desa setempat dan kegiatan pembangunan Pura. Biaya operasional ini juga digunakan untuk gaji karyawan, dan pemeliharaan fasilitas.

Tabel 2 Pendapatan dan Distribusi Pendapatan Tahun 2014

\begin{tabular}{|c|c|c|c|c|c|c|c|c|}
\hline \multirow[b]{2}{*}{ No } & \multirow[b]{2}{*}{ Bulan } & \multirow[b]{2}{*}{$\begin{array}{c}\text { Jumlah } \\
\text { Kujungan }\end{array}$} & \multirow[b]{2}{*}{$\begin{array}{l}\text { Harga } \\
\text { Tiket }\end{array}$} & \multirow[b]{2}{*}{$\begin{array}{c}\text { Pendapatan } \\
\text { (Jml Kunjungan } \\
\text { X Harga Tiket) }\end{array}$} & \multicolumn{4}{|c|}{ Distribusi Pendapatan } \\
\hline & & & & & $\begin{array}{c}\text { Biaya } \\
\text { Operasional } \\
(32.34 \%)\end{array}$ & $\begin{array}{c}\text { Desa Palcraman } \\
\text { Tegallalang } \\
(35 \%)\end{array}$ & $\begin{array}{l}\text { Investasi } \\
(30 \%)\end{array}$ & $\begin{array}{c}\text { Asuransi } \\
\text { Kesehatan } \\
(2.66 \%)\end{array}$ \\
\hline 1 & Januari & 23,000 & 5,000 & $115,000,000$ & $37,191,000$ & $40,250,000$ & $34,500,000$ & $3,059,000$ \\
\hline 2 & Februari & 23,500 & 5,000 & $117,500,000$ & $37,999,500$ & $41,125,000$ & $35,250,000$ & $3,125,500$ \\
\hline 3 & Maret & 23,600 & 5,000 & $118,000,000$ & $38,161,200$ & $41,300,000$ & $35,400,000$ & $3,138,800$ \\
\hline 4 & April & 22,500 & 5,000 & $112,500,000$ & $36,382,500$ & $39,375,000$ & $33,750,000$ & $2,992,500$ \\
\hline 5 & Mei & 24,100 & 5,000 & $120,500,000$ & $38,969,700$ & $42,175,000$ & $36,150,000$ & $3,205,300$ \\
\hline 6 & Juni & 24,175 & 5,000 & $120,875,000$ & $39,090,975$ & $42,306,250$ & $36,262,500$ & $3,215,275$ \\
\hline 7 & Juli & 29,200 & 5,000 & $146,000,000$ & $47,216,400$ & $51,100,000$ & $43,800,000$ & $3,883,600$ \\
\hline 8 & Agustus & 30,800 & 5,000 & $154,000,000$ & $49,803,600$ & $53,900,000$ & $46,200,000$ & $4,096,400$ \\
\hline 9 & September & 29,100 & 5,000 & $145,500,000$ & $47,054,700$ & $50,925,000$ & $43,650,000$ & $3,870,300$ \\
\hline 10 & Oktober & 27,400 & 5,000 & $137,000,000$ & $44,305,800$ & $47,950,000$ & $41,100,000$ & $3,644,200$ \\
\hline 11 & Nopember & 23,700 & 5,000 & $118,500,000$ & $38,322,900$ & $41,475,000$ & $35,550,000$ & $3,152,100$ \\
\hline 12 & Desember & 24,300 & 5,000 & $121,500,000$ & $39,293,100$ & $42,525,000$ & $36,450,000$ & $3,231,900$ \\
\hline Jun & nlah Total & 305,375 & & $1,526,875,000$ & $493,791,375$ & $534,406,250$ & $458,062,500$ & $40,614,875$ \\
\hline
\end{tabular}

Desa Pakraman Tegallalang menerima bagian pendapatan daya tarik wisata Ceking dalam jumlah yang paling banyak (35\%) karena Desa PakramanTegallalang merupakan desa yang bertindak sebagai pengelola daya tarik wisata Ceking. Pendapatan ini digunakan untuk keperluan pembangunan desa dan memperbaiki fasilitas yang rusak. Pendapatan sebesar 30\% digunakan untuk investasi seperti pembelian lahan parkir, perbaikan fasilitas di daya tarik wisata yang rusak. Untuk asuransi kesehatan dianggarkan sebesar 2,66\% dari pendapatan yang diperoleh oleh BPOWC. Dari distribusi itu, untuk tahun 2014, misalnya, pihak desa mendapat pemasukan Rp 534,4 juta yakni setengah milyar lebih.

Sejak daya tarik wisata Ceking dikelola oleh BPOWC pada tahun 2011, Pemerintah Daerah Kabupaten Gianyar khususnya Dinas Pariwisata tidak mendapatkan bagian dari pendapatan BPOWC.BPOWC diberikan hak sepenuhnya dalam mengelola dan memanfaatkan hasil dari pendapatannya karena daya tarik Ceking masih dalam tahap pengembangan dan penataan. Penataan DTW masih belum mapan dan tiket masuknya pun masih relatif murah.Di samping itu, BPOWC selaku badan pengelola juga masih baru 
dalam menjalankan tugasnya sehingga masih perlu penyesuaian.Oleh sebab itu, karena masih dalam tahap uji coba maka belum memberikan pembagian pendapatan ke Pemerintah Kabupaten Gianyar.Hal inidibenarkan oleh Jero Penyarikan Desa Pakraman Tegallalang dengan memberikan pernyataan sebagai berikut.

"BPOWC baru dibentuk pada tahun 2011.Ceking masih memerlukan banyak penataan.Karena masih dalam tahap uji coba, untuk saat ini Pemda mempercayakan kami untuk mengelola sendiri pendapatan BPOWC dari penjualan tiket masuk dan dana pacingkrem. Kami juga belum memberikan bagian pendapatan ke Pemda karena alasan tadi.Nanti apabila penataan sudah bagus, tarif tiket masuk akan kami naikkan. Dan jika sudah seperti itu, maka Pemda akan mendapat bagian dari pendapatan BPOWC" (Wawancara 22 Desember 2014).

Pernyataan tersebut menegaskan bahwa pendapatan BPOWC saat ini belum dibagikan ke Pemerintah Kabupaten Gianyar karena selain BPOWC baru dibentuk, daya tarik wisata Ceking juga masih memerlukan banyak dana untuk penataan agar menjadi sebuah daya tarik wisata yang menarik untuk dikunjungi wisatawan.

Pendapatan juga diberikan sebagai kompensasi kepada petani pemilik sawah. Pada awalnya BPOWC membuat surat perjanjian dengan petani pemilik lahan untuk jangka waktu 10 (sepuluh) tahun. Namun karena ketidakpuasan para petani pada saat menerima kompensasi yang terlalu kecil (pada awalnya berjumlah $\mathrm{Rp}$ 500.00o/ bulan), maka perjanjian tersebut diubah berdasarkan kesepakatan bersama dengan jangka waktu perpanjangan tiap 2 (dua) tahun. Hal ini dikarenakan keinginan petani yang tidak ingin lahan sawahnya dikontrak dalam waktu yang lama dengan kompensasi yang kecil. Petani pemilik lahan memiliki asumsi bahwa kompensasi bisa dinaikkan setiap 2 tahun sekali yang disesuaikan dengan pemasukan BPOWC dan harga kontrak tanah yang berlaku di Bali. Kompensasi yang diminta semula oleh petani adalah Rp 3.000.00o / bulan. Karena dinilai terlalu besar, berdasarkan kesepakatan bersama maka kompensasi yang diterima petani setiap bulannya berjumlah Rp 2.00o.ooo. Kompensasi ini merupakan solusi agar petani tidak merasa dimanfaatkan, tetapi ikut menikmati manfaat dari kegiatan pariwisata.

\section{Partisipasi Masyarakat dalam Pengembangan DTW Ceking 4.1 Karakteristik Masyarakat}

Masyarakat Desa Tegallalang merupakan masyarakat yang masih menjalankan kegiatan sehari-hari dengan cara yang masih sederhana dan mencerminkan kehidupan masyarakat pedesaan. Selain itu, masyarakat 
juga masih menjalankan tradisi leluhurnya dengan baik. Masyarakat Desa Tegallalang sangat ramah baik dengan sesama masyarakat setempat maupun dengan para pendatang. Masyarakat Desa Tegallalang cenderung bersikap hati-hati dalam mengambil keputusan terutama yang menyangkut daya tarik wisata Ceking agar tidak terjadi kesalahpahaman mengingat sebagian daya tarik wisata ini terletak di perbatasan Desa Kedisan.

Petani pemilik lahan yang lahan sawahnya dijadikan sebagai daya tarik wisata Ceking juga sangat ramah. Petani pemilik lahan ini merupakan masyarakat Desa Kedisan. Hal ini karena daya tarik wisata Ceking itu sendiri sebagian besar merupakan wilayah Desa Kedisan. Setiap ada wisatawan yang datang selalu disapa dengan ramah, walaupun dengan perbendaharaan bahasa asing yang sangat terbatas. Namun, ada kalanya petani pemilik lahan ini bersikap apatis karena merasa potensi yang dimilikinya dimanfaatkan untuk kepentingan ekonomi oleh masyarakat Desa Pakraman Tegallalang. Petani pemilik lahan pernah memasang seng atau instalasi karena keinginannya tidak dituruti. Bahkan, untuk meraup keuntungan yang maksimal maka para petani ini tidak segan-segan untuk memaksa wisatawan yang melewati lahan sawahnya memberikan donasi walaupun wisatawan tersebut sudah membayar tiket masuk dan donasi sebelumnya.

\subsection{Bentuk Partisipasi}

Partisipasi masyarakat Tegallalang sesuai dengan yang dinyatakan oleh Mikkelsen di mana masyarakat secara aktif dan mengambil inisiatif untuk berpartisipasi dalam pengembangan dan pengelolaan daya tarik wisata Ceking. Partisipasi masyarakat tersebut didorong oleh perkembangan daya tarik wisata Ceking dari sebelum ditetapkan sampai setelah ditetapkan sebagai daya tarik wisata oleh Pemerintah Kabupaten Gianyar kondisi daya tarik wisata Ceking tidak menunjukkan perbaikan dan kurang memberikan kontribusi ekonomi bagi masyarakat setempat. Sifat partisipasi masyarakat Desa Pakraman Tegallalang adalah partisipasi transformasional yaitu partisipasi yang terjadi ketika partisipasi itu pada dirinya sendiri dipandang sebagai tujuan, dan sebagai sarana untuk mencapai tujuan yang lebih tinggi, misalnya menjadi swadaya dan berkelanjutan. Masyarakat melakukan swadaya untuk melakukan pengelolaan dan penataan daya tarik wisata Ceking untuk memperluas lapangan pekerjaan dan memperoleh manfaat ekonomi sehingga daya tarik wisata Ceking akan berkembang secara berkelanjutan

Pengembangan daya tarik wisata Ceking sudah dilaksanakan dengan menggunakan kekuatan rakyat/masyarakat setempat. Masyarakat Desa Pakraman Tegallalang telah berpartisipasi dalam pembangunan pariwisata di daya tarik wisata Ceking. Bentuk partisipasi tersebut meliputi: Pertama, partisipasi dalam membuat keputusan yaitu masyarakat ikut serta dalm 
sangkep banjar (rapat komunitas) untuk membahas penataan daya tarik wisata Ceking. Dalam sangkep banjar tersebut terbentuk BPOWC.

Kedua, partisipasi dalam pelaksanaan keputusan yaitu melaksanakan segala hal yang telah diputuskan dalam sangkep banjar untuk menata dan mengelola daya tarik wisata Ceking diantaranya ikut berpartisipasi dalam menjaga kebersihan, menjaga keamanan, menata bangunan, dan menyediakan fasilitas penunjang.

Ketiga, partisipasi dalam memperoleh manfaat yaitu masyarakat membuka artshop, warung, cafe maupun restoran. Dan keempat, partisipasi dalam evaluasi yaitu BPOWC dan aparat Desa Pakraman Tegallalang mengadakan rapat evaluasi yang dilakukan sebulan sekali untuk membahas masalah yang terjadi di daya tarik wisata Ceking dan seberapa jauh penataan yang sudah dilakukan.

\subsection{Manfaat Partisipasi}

Manfaat dari partisipasi yang dilakukan masyarakat yaitu penciptaan lapangan kerja yang lebih luas untuk masyarakat, pendukung pelestarian budaya, adanya keyakinan yang lebih menjamin bagi upaya pelestarian sumber daya masyarakat setempat, dan adanya keuntungan ekonomi yang secara langsung dinikmati oleh masyarakat. Masyarakat Desa Pakraman Tegallang diberikan lapangan kerja untuk menjadi karyawan BPOWC, pelayan restoran, penjaga artshop, dan bisa juga menjadi guide lokal bagi wisatawan selama berada di daya tarik wisata Ceking.

Partisipasi masyarakat lokal dalam pengembangan daya tarik wisata Ceking memberikan dukungan dalam pelestarian budaya pertanian yang ada di daya tarik wisata Ceking, dan juga budaya lainnya yaitu budaya dalam membuat kerajinan kayu yang ada di sekitar daya tarik wisata Ceking. Budaya-budaya tersebut tidak akan hilang karena justru budaya itulah yang dikembangkan dan dijadikan sebagai daya tarik wisata di Ceking. Budaya pertanian berupa pengolahan lahan sawah berundak-undak merupakan daya tarik utama, ditambah lagi dengan dikenalnya Desa Tegallalang sebagai sentra kerajinan kayu membuat wisatawan tertarik untuk mengunjunginya.

Pelestarian sumber daya masyarakat setempat juga bisa terjamin karena sumber daya tersebut dilaksanakan secara terus-menerus dalam kehidupan masyarakat setempat. Budaya pertanian yang dilakukan para petani (masyarakat Desa Kedisan) membuat sawah-sawah tetap eksis di tengahtengah konversi lahan yang marak terjadi di Bali di mana aktivitas pertanian tersebut di samping dilakukan untuk menjalankan amanah para leluhur juga untuk kelestarian alam sekitar. Desa Tegallalang juga dikenal sebagai pusat kerajinan seni juga berusaha untuk mempertahankan keahliannya dalam membuat kerajinan kayu karena kerajinan tersebut dapat dijadikan sebagai cenderamata bagi wisatawan yang berkunjung ke Desa Tegallalang pada 
umumnya dan daya tarik wisata Ceking pada khususnya.

Keuntungan ekonomi yang diterima oleh masyarakat dari partisipasinya adalah BPOWC (Desa Pakraman Tegallalang) memperoleh pendapatan dari penjualan tiket masuk dan dana pacingkrem dari pengusaha pariwisata. Masyarakat sendiri mendapatkan keuntukngan ekonomi dengan membuka artshop, restoran, café dan warung. Ada juga masyarakat Tegallalang yang menyewakan tokonya untuk orang lain, sehingga dari sewa tersebut masyarakat juga memperoleh pemasukan. Sewa tersebut bervariasi dari harga Rp 15.000.000 sampai Rp. 25.000.000 per tahun tergantung dari besar toko dan akses untuk melihat view sawah berundak. Hal ini juga diakui oleh Nyoman Wiranata selaku salah satu pedagang cinderamata di daya tarik wisata Ceking yang memberikan pernyataan sebagai berikut.

\begin{abstract}
"Tyang (saya) sudah lama berjualan di sini. Sudah hampir 20 tahun. Kios ini bukan milik tiang, tiang sewa dari orang desa sini seharga Rp.15.00o.ooo per tahun. Sewa masing-masing kios di sini tidak sama. Untuk retribusi kami bayar Rp. 50.000 per bulan, Rp 25.00o untuk pengelola dan Rp 25.00o lagi untuk kebersihan. Biar petani tidak ngambul, tidak pasang seng lagi, tidak pasang-pasang tulisan, kami bayar Rp 60.000 untuk view sawah ke petani. Ya...walaupun begitu, tiang masih bersyukur berkat ada yang mengelola lingkungan jadi bersih, bebas dari dari pedagang acung. Pendapatan tiang juga meningkat" (Wawancara 4 Februari 2015).
\end{abstract}

Dari pernyataan tersebut, diketahui bahwa masyarakat Desa Pakraman Tegallalang berpartisipasi dalam menyediakan fasilitas kepariwisataan di daya tarik wisata Ceking. Walaupun masyarakat tersebut sebagian besar tidak terjun langsung untuk berdagang, tetapi dari hasil penyewaan bangunan masyarakat mendapatkan manfaat secara ekonomi dari kegiatan pariwisata yang berlangsung di sekitar daya tarik wisata Ceking. Apalagi setelah kunjungan wisatawan ke daya tarik wisata Ceking meningkat, maka sewa bangunan tersebut juga meningkat.

Partisipasi masyarakat di daya tarik wisata Ceking memberikan keuntungan ekonomi yang secara langsung diterima oleh masyarakat. Desa Pakraman Tegallalang memperoleh pendapatan dari penjualan tiket masuk ke daya tarik wisata Ceking. Pendapatan tersebut selain untuk kegiatan operasional juga digunakan untuk pembangunan Desa Tegallalang. Masyarakatnya pun memperoleh keuntungan ekonomi dengan membuka restoran, warung, café dan artshop baik yang dikelola sendiri maupun disewakan kepada pihak lain. Besarnya nilai sewa tersebut berkisar Rp 6.000.000 - Rp 25.000.00o tergantung lokasi dan view sawah yang didapat.

Di pihak petani pemilik lahan yaitu masyarakat Desa Kedisan juga memperoleh manfaat ekonomi secara langsung yaitu menerima kompensasi 


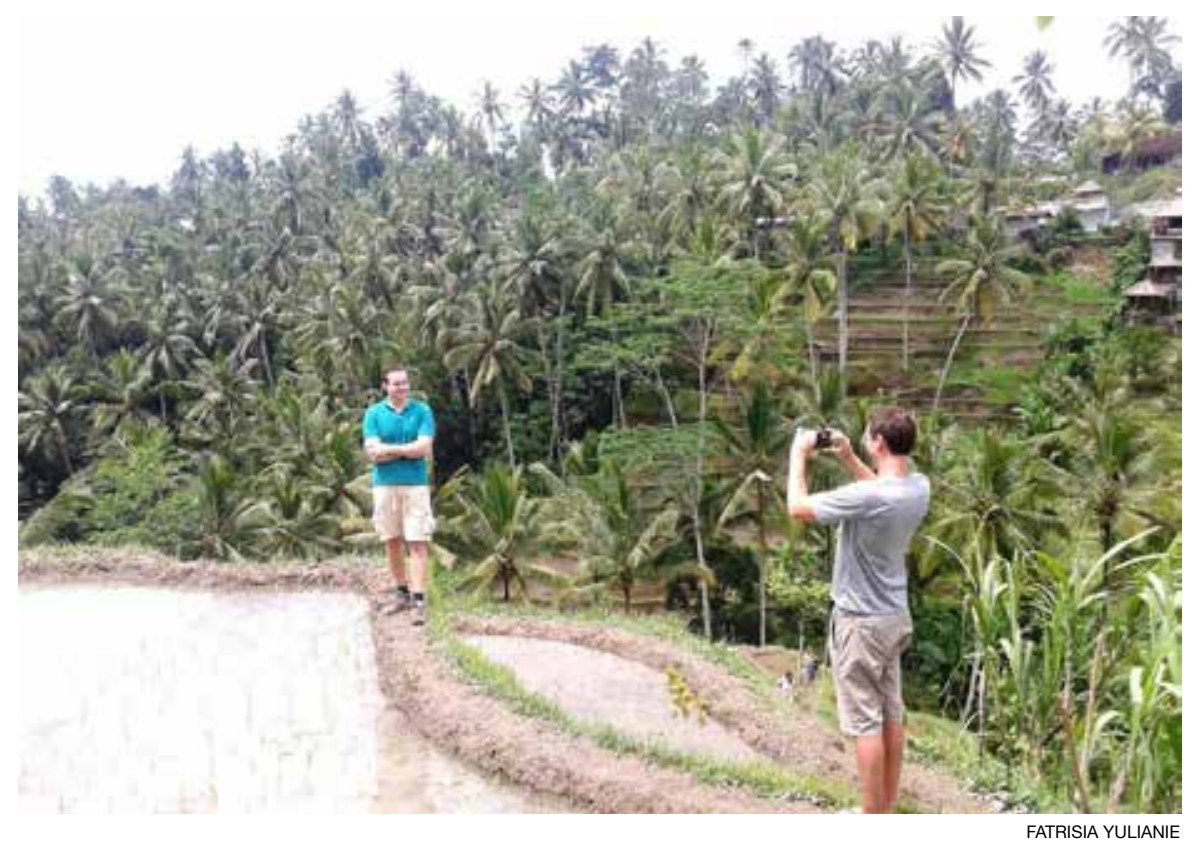

Foto 3. Wisatawan mancanegara yang berkunjung ke Ceking, senang berfoto di sawah.

sebesar Rp 2.000.000/bulan dari BPOWC, donasi dari wisatawan dan pendapatan lainnya dari penjualan kelapa muda, kartu pos, kerajinan topi petani dan juga jasa menjadi objek foto. Hal tersebut dibenarkan oleh salah satu pemilik lahan (Made Sutha) sebagai berikut.

“Sejak dikelola Desa Pakraman, tyang mendapat pendapatan yang lumayan. Tiap bulan sekarang dapat uang Rp 2.00o.0oo dari pengelola, ditambah lagi dari hasil jualan kelapa muda dan donasi. Bandingkan dengan pendapatan dari hasil panen sih jauh. Sekali panen per 3 bulan hanya dapat 3 karung beras, itu pun sudah dikurangi dengan biaya buruh Rp 85.000 per hari dan tanggungan kopi dan makannya. Jadi, kalau dihitung-hitung Tiang hanya dapat 1 karung beras, sedangkan 2 karungnya lagi anggap untuk menutupi upah buruh" (Wawancara 11 Januari 2015).

Dari pernyataan tersebut dapat diketahui baik berpartisipasi secara aktif maupun pasif, masyarakat di sekitar daya tarik wisata Ceking memperoleh manfaat secara ekonomi dari kegiatan pariwisata yang berlangsung di daya tarik wisata Ceking. Petani mendapatkan pendapatan yang lebih besar dari hasil sawahnya sehingga dengan demikian petani memperoleh manfaat ganda dari partisipasi yang dilakukannya dalam kegiatan pariwisata Ceking yaitu pendapatan meningkat dan sawahnya tetap lestari keberadaannya karena terus diolah dan dijadikan daya tarik wisata (Foto 3). 


\section{Pemberdayaan Masyarakat dalam Pengembangan DTW Ceking}

Daya tarik wisata Ceking secara geografis berada di wilayah perbatasan dua desa yaitu Desa Tegallalang dan Desa Kedisan. Daya tarik utama Ceking yang berupa sawah berundak merupakan wilayah Desa Kedisan tepatnya Banjar Kebon. Sedangkan wilayah sebelah barat jurang yang selama ini menjadi tempat perhentian dan tempat terbaik untuk menikmati panorama terrasering Ceking berada di wilayah administrasi Desa Tegallalang tepatnya Banjar Tegallalang. Kondisi wilayah administrasi daya tarik wisata Ceking tersebut merupakan sebuah tantangan dalam pengelolaan daya tarik wisata yang berbasiskan masyarakat melalui pembukaaan ruang partisipasi bagi masyarakat lokal. Kedua komunitas tersebut memiliki inisiatif dan keinginan untuk terlibat dalam pengelolaan atas dasar hak wilayah guna memperoleh manfaat ekonomi dari perkembangan wisata Ceking untuk membangun komunitasnya masing-masing.

Keinginan masyarakat dalam pengembangan dan pengelolaan potensi wisata yang ada di wilayahnya tidak terlepas dari pergeseran paradigma pembangunan khususnya pembangunan pariwisata di Bali. Dewasa ini paradigma pembangunan pariwisata oleh pemerintah mengarah pada pembangunan yang bersifat bottom up. Dimana pemerintah membuka ruang yang lebih luas bagi masyarakat untuk berpartisipasi dalam pembangunan khususnya pembangunan pariwisata. Partisipasi masyarakat dalam pembangunan pariwisata di Bali dengan memberikan kesempatan masyarakat untuk mengembangkan dan mengelola potensi wisata yang ada telah banyak yang berhasil dalam meningkatkan kesejahteraan masyarakat setempat dan rasa tanggung jawab dalam menjaga potensi wisata yang ada. Keberhasilan masyarakat daerah lain dalam mengembangkan dan mengelola daya tarik wisata yang ada telah mendorong masyarakat Desa Tegallalang sebagai sebuah komunitas untuk mengelola dan mengembangkan daya tarik wisata Ceking dengan harapan untuk menjaga keberlangsungan daya tarik dan mengoptimalkan manfaat ekonomi pariwisata bagi masyarakat setempat.

Pembangunan berbasis komunitas merupakan paradigma alternatif terhadap kegagalan paradigma birokratis yang dianggap menciptakan ketergantungan masyarakat perdesaan terhadap birokrasi. Demikian juga dengan pengelolaan dan pengembangan daya tarik wisata Ceking dikelola dengan menerapkan manajemen komunitas yaitu Desa Pakraman Tegallalang melalui BPOWC. Sebelum ditetapkan sebagai salah satu daya tarik wisata di Kabupaten Gianyar daya tarik wisata Ceking tidak dikelola secara profesional, begitu pun ketika ditetapkan sebagai daya tarik wisata pada tahun 2008 oleh Pemerintah Kabupaten Gianyar keadaan daya tarik wisata Ceking tidak menunjukkan perubahan ke arah yang lebih baik. Daya tarik wisata Ceking dinilai semakin semrawut dan terlihat kumuh. Melihat 
keadaan yang demikian, maka Desa Pakraman Tegallalang sebagai sebuah komunitas masyarakat adat berinisiatif untuk membentuk badan pengelola yang disebut BPOWC sebagai pengelola. Pembentukan badan pengelola ini dilakukan oleh Desa Pakraman Tegallalang sebagai salah satu komunitas yang ada di daya tarik wisata Ceking, tanpa melibatkan Desa Kedisan sebagai sebuah komunitas, melainkan hanya melibatkan masyarakat pemilik lahan terrasering saja. Masyarakat Tegallalang beranggapan mereka lebih berhak mengelola karena jalur utama dan tempat wisatawan untuk melihat view Ceking berada di wilayah Desa Tegallalang.

\subsection{Pemberdayaan Masyarakat oleh Pemerintah Kabupaten Gianyar}

Program pemberdayaan masyarakat yang dilakukan oleh pemerintah Kabupaten Gianyar adalah: Pendidikan dan pembinaan masyarakat tentang pariwisata. Program pendidikan dan pelatihan diberikan oleh pemerintah dalam rangka meningkatkan kesadaran dan pengetahuan masyarakat tentang kepariwisataan. Memberi ruang dan kesempatan pada masyarakat untuk mengembangkan dan mengelola daya tarik wisata Ceking dengan membentuk badan pengelola. Badan pengelola yang melibatkan masyarakat Desa Pakraman Tegallalang dibentuk untuk melakukan pengelolaan dan penataan daya tarik wisata Ceking. Sejak tahun 2011 berdasarkan Peraturan Bendesa Desa Pakraman Tegallalang Nomor: 055/VI/DPT/2011 tentang Penataan Wilayah Ceking maka secara resmi daya tarik wisata Ceking dikelola oleh Desa Pakraman Tegallalang dalam sebuah badan pengelola yang dinamakan Badan Pengelola Objek Wisata Ceking (BPOWC). Dalam badan pengelola ini tidak melibatkan unsur dari pemerintah dalam pengelolaan. Memberikan hak secara penuh bagi masyarakat dalam mengembangkan dan memanfaatkan hasil pengelolaan daya tarik wisata Ceking. Bentuk pemberdayaan yang lain adalah dengan memberikan keleluasaan pada masyarakat Tagallalang untuk memanfaatkan secara penuh hasil perolehan dari pengelolaan daya tarik wisata Ceking untuk kepentingan masyarakat, pengembangan dan pengelolaan daya tarik Ceking.

\subsection{Program Penataan Daya Tarik Wisata Ceking}

Daya tarik wisata Ceking yang saat ini dikelola oleh Desa Pakraman Tegallalang melalui Badan Pengelola Objek Wisata Ceking (BPOWC) dalam pengembangannya telah menunjukkan kemajuan baik dalam kenyamanan wisatawan, penataan daya tarik dan distribusi manfaat ekonomi. Keadaan ini jauh berbeda dengan kondisi sebelum daya tarik wisata Ceking dikelola oleh Desa Pakraman Tegallalang, dimana keadaan sebelumnya tidak tertata, tidak ada pengelola sehingga menimbulkan berbagai macam permasalahan. Untuk mengatasi permasalahan yang ada, maka dibuatlah rencana penataan 
agar daya tarik wisata Ceking menjadi semakin menarik dan memberikan kenyamanan bagi wisatawan yang berkunjung.

Rencana penataan yang dilakukan oleh BPOWC yaitu: Merencanakan tempat parkir beserta perlengkapannya seperti: kantor (Information center dan ruang jaga), toilet, tempat tunggu sopir. Gate way 2 buah (pintu masuk Utara dan Selatan, dilengkapi loket karcis masuk / parkir. Pembuatan trotoar di sebelah kanan dan kiri sepanjang jalan Raya Ceking (untuk pejalan kaki dan tempat menikmati pemandangan yang di sebelah timur. Membuat Toilet di beberapa tempat di dalam kawasan. Merencanakan lampu di areal parkir. Membuat jalan untuk pejalan kaki (trekking) beberapa jalur di dalam kawasan. Membuat tempat istirahat sementara (rest area) dan Stop Over di beberapa tempat di dalam kawasan. Merencanakan tempat-tempat sampah yang fleksibel untuk sampah jenis organik dan anorganik. Mengatur dan menjaga kenyamanan dan keamanan wisatawan.

Sebagian dari rencana penataan tersebut sudah terealisasi seperti tempat parkir dan perlengkapannya, gate way, dan membuat jalur tracking. Sementara untuk trotoar, toilet di beberapa tempat, rest area, stop over dan tempat-tempat sampah yang fleksibel sedang diusahakan keberadaanya.

\subsection{Keberhasilan Pemberdayaan Masyarakat di Daya Tarik Wisata Ceking}

Masyarakat Desa Pakraman Tegallang diberikan ruang dan kesempatan untuk berpartisipasi baik terlibat secara langsung dalam BPOWC maupun melakukan kegiatan usaha di sekitar daya tarik wisata Ceking. Lahan persawahan yang dijadikan sebagai daya tarik wisata utama di Ceking merupakan milik masyarakat Desa Kedisan. Petani pemilik lahan juga diberdayakan dengan diberikan ruang dan kesempatan untuk berpartisipasi dengan menggarap sawahnya seperti biasa, menjual kerajinan tangan berupa topi petani, dan menjual buah kelapa kepada wisatawan. Selain itu, petani pemilik lahan juga diberikan kesempatan untuk meminta donasi kepada wisatawan asalkan jangan memintanya dengan cara yang memaksa.

Untuk memantapkan program pengelolaan dan pengembangan di daya tarik wisata Ceking, maka masyarakat Desa Pakraman Tegallalang pada umumnya dan BPOWC pada khususnya diberikan pendidikan dan pembinaan berupa penyuluhan yang diberikan Dinas Pariwisata Kabupaten Gianyar. Selanjutnya pihak BPOWC memberikan pendidikan dan pelatihan kepada para pemilik usaha wisata yang ada di sekitar daya tarik wisata Ceking dan petani pemilik lahan.

Di dalam daya tarik wisata Ceking terdapat dua komunitas besar yaitu masyarakat Desa Pakraman Tegallalang selaku pengelola dan masyarakat Desa Kedisan selaku pemilik lahan persawahan (Foto 4). Di antara kedua komunitas ini sering terjadi konflik terkait pengembangan dan pengelolaan 


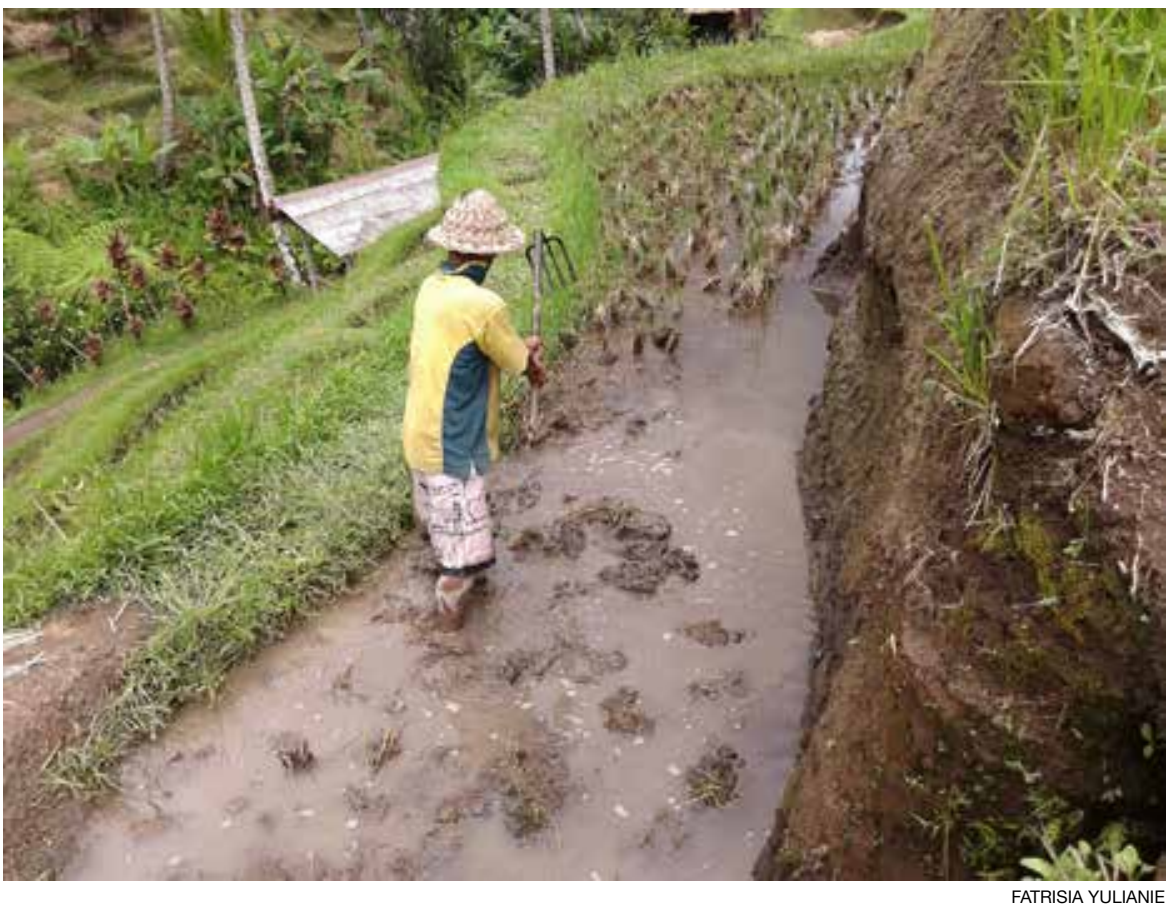

Foto 4. Petani di teras sawah Ceking menggarap sawah menambah unik daya tarik wisata Ceking.

daya tarik wisata Ceking karena masyarakat Desa Kedisan merasa belum mendapatkan manfaat yang maksimal dari kegiatan pariwisata yang berlangsung di daerahnya. Perbedaan karakteristik kedua komunitas juga menjadikannya kendala dalam pemberdayaan masyarakat dalam pengelolaan dan pengembangan daya tarik wisata Ceking.

\subsection{Program Pemberdayaan Masyarakat yang perlu Dilakukan}

Banyaknya kendala yang dihadapi dalam pemberdayaan masyarakat maka perlu adanya program untuk memberdayakan masyarakat Desa Kedisan lebih optimal. Pemberdayaan tersebut bisa dilakukan dengan beberapa cara yaitu: Dengan melibatkan masyarakat Desa Kedisan dalam BPOWC, petani selain diberikan kompensasi karena sawahnya digunakan sebagai daya tarik wisata juga diberikan gaji per bulan untuk pemeliharaan sawahnya. Pembentukan Badan pengelola dengan melibatkan Desa Pakraman Tegallalang dan Desa Kedisan yang didukung oleh pemerintah dan pelaku wisata dalam melakukan pengelolaan dan pengembangan daya tarik wisata Ceking. Tidak hanya Desa Pakraman Tegallalang yang selalu dominan dalam pengelolaan, tetapi pengelolaan daya tarik wisata Ceking juga memerlukan dukungan dari komunitas lainnya yaitu Desa Kedisan yang merupakan pemilik potensi daya tarik wisata Ceking.

Program pendidikan dan pembinaan yang berkelanjutan bagi pengelola 
dan masyarakat setempat khususnya para petani pemilik lahan. Program pemberdayaan masyarakat lokal untuk menjadi pemandu bagi wisatawan yang akan melakukan aktivitas wisata trekking di Ceking. Masyarakat lokal khususnya para petani pemilik lahan pertanian di Ceking selain sebagai pekerja badan pengelola yang bertugas merawat sawahnya juga bisa menjadi pemandu bagi wisatawan yang melakukan trekking.

Program dalam mengatasi permasalahan kemacetan di areal jalan daya tarik wisata Ceking. Program yang telah dilakukan oleh badan pengelola adalah pengadaan tempat parkir yang telah dioperasionalkan sejak Desember 2014. Namun tempat parkir ini jarang dimanfaatkan oleh sopir karena jaraknya yang cukup jauh dari view daya tarik wisata Ceking. Beberapa program yang bisa dilakukan yaitu: Mewajibkan seluruh pengemudi (kecuali Bus) setelah menurunkan wisatawan di stop over untuk kembali memarkirkan kendaraannya di lahan parkir yang telah disediakan, dan saat wisatawan telah selesai melakukan kunjungan, maka petugas pengelola akan memanggil pengemudi untuk menjemput wisatawan di stop over. Semua kendaraan pengantar tamu diwajibkan masuk ke areal parkir (kecuali bus) dan wisatawan akan diturunkan di parkir yang selanjutnya diangkut dengan kendaraan khusus pengangkut wisatawan ke stop over yang disediakan oleh badan pengelola dengan didampingi petugas (pemandu lokal).

\section{Tanggapan Wisatawan terhadap Daya Tarik Wisata Ceking}

Dalam penelitian yang dilakukan, untuk mengetahui respon atau tanggapan wisatawan terhadap daya tarik wisata Ceking maka dilakukan penyebaran angket yang ditujukan kepada 30 orang wisatawan yang berkunjung ke daya tarik tersebut. Berdasarkan angket yang disebarkan dapat diketahui wisatawan memperoleh informasi mengenai daya tarik wisata Ceking dari teman dan keluarganya (36,67\%) dan ada juga yang mendapatkan informasi dari brosur (26,67\%). Wisatawan mengorganisir sendiri perjalanannya ke daya tarik wisata Ceking (53,33\%) dan ada wisatawawan menggunakan jasa agen perjalanan untuk mengorganisir perjalanannya (10\%).

Wisatawan mengaku pernah mengunjungi daya tarik wisata Ceking sebelumnya (40\%), dan sisanya belum pernah berkunjung sebelumnya (6o\%). Hal ini menunjukkan bahwa daya tarik wisata Ceking menarik untuk dikunjungi baik karena keindahan, keamanan, maupun kenyamanannya, sehingga ada wisatawan yang datang berulangkali dan berniat untuk berkunjung lagi di kemudian hari (70\%).

Sebagian besar wisatawan yang berkunjung ke daya tarik wisata Ceking untuk menikmati suasana alam Ceking (90\%). Atraksi wisata alam yang paling menarik bagi wisatawan adalah sawah berundak (80\%) dan atraksi budaya berupa cara mengolah sawah yang dilakukan petani (16,67\%). Ada 
juga yang menjadikan daya tarik wisata Ceking sebagai stop over pada waktu makan siang, sehingga wisatawan bisa menikmati hidangannya sambil melihat pemandangan sawah Ceking (16,67\%).

Waktu durasi kunjungan wisatawan beranekaragam mulai dari yang berkunjung hanya selama 15 menit, bahkan ada yang sampai 4 jam. Semua ini tergantung dari aktivitas yang dilakukan wisatawan selama berada di daya tarik wisata Ceking.

Informasi yang didapat dari angket menyebutkan bahwa wisatawan menilai fasilitas yang tersedia di daya tarik wisata Ceking dinilai baik (53,33\%), wisatawan merasa aman (56,67\%) dan merasa sangat aman (40\%). Kenyamanan selama berada di daya tarik wisata Ceking tersebut bervariasi, wisatawan merasa nyaman (80\%), merasa sangat nyaman $(16,67 \%)$ dan merasa tidak nyaman (3,33\%).

Hanya saja yang banyak mendapat sorotan dari wisatawan adalah area parkir, artshop, warung dan toilet dinilai buruk dalam hal penataan dan penyediaannya. Sebanyak 33,33\% wisatawan menilai area lahan parkir buruk. Fasilitas yang dinilai buruk lainnya adalah artshop dan warung (30\%) dan WC/toilet (26,67\%). Hal ini bisa dimaklumi karena sebagian besar wisatawan tersebut tidak mengetahui bahwa BPOWC sudah menyediakan central parkir yang luas dan dilengkapi dengan 6 unit toilet bersih, ruang tunggu sopir dan disediakan payung untuk wisatawan apabila terjadi hujan ketika berkunjung ke daya tarik wisata Ceking. Banyak sopir dan pramuwisata enggan untuk memarkir kendaraannya di central parkir tersebut.

Wisatawan mendukung daya tarik wisata Ceking dikembangkan dengan mengutamakan pelestarian lingkungan alam (sangat sependapat 80\% dan sependapat 20\%), ekonomi masyarakat lokal (sangat sependapat 53,33\% dan sependapat 46,67\%), dan perlindungan sosial budaya setempat (sangat sependapat 70\% dan sependapat 30\%). Pengembangan daya tarik wisata Ceking dapat dilakukan asalkan tidak merusak lingkungan baik lingkungan alam, ekonomi, maupun budaya. Wisatawan juga berharap agar pengembangan daya tarik wisata Ceking memberikan pendapatan yang lebih kepada petani dan memberikan peluang berusaha serta kesempatan kerja bagi masyarakat lokal.

\section{Model Pengelolaan yang Tepat untuk DTW Ceking}

Berdasarkan permasalahan pengelolaan yang telah disampaikan sebelumnya, maka model pengelolaan yang tepat untuk daya tarik wisata Ceking adalah pengelolaan oleh badan pengelola. Jadi, untuk pengelolaan daya tarik wisata Ceking yang sekarang sudah bagus. Hanya saja untuk ke depannya model pengelolaan oleh badan pengelola (BPOWC) ini diharapkan dapat mengetengahkan konsep keterpaduan antara unsur-unsur yang terlibat dalam daya tarik wisata, seperti: desa adat, subak, pemerintah, 
pelaku pariwisata dan tentu saja masyarakat Desa Kedisan.

Semua komponen yang terlibat secara bersama-sama mengelola daya tarik wisata dengan perannya masing-masing yang disepakati bersama. Model ini diharapkan dapat mengurangi permasalahan-permasalahan yang dihadapi dalam pengelolaan selama ini.

\section{Simpulan dan Saran}

Darihasilpenelitianini dapat ditariksimpulan sebagaiberikut: Masyarakat Desa Pakraman Tegallalang ikut berpartisipasi dalam pengembangan dan pengelolaan daya tarik wisata Ceking. Bentuk partisipasi masyarakat Desa Pakraman Tegallalang tersebut yaitu partisipasi dalam membuat keputusan, partisipasi dalam pelaksanaan keputusan, partisipasi dalam memperoleh manfaat, dan partisipasi dalam evaluasi. Pemberdayaan masyarakat dalam pengelolaan daya tarik wisata Ceking belum optimal karena tidak semua komunitas terlibat di dalamnya. Tanggapan wisatawan terhadap daya tarik wisata Ceking menarik untuk dikunjungi, sementara sarana dan fasilitas wisata perlu ditingkatkan.

Berdasarkan penelitian yang dilakukan maka dapat diajukan saran yaitu: Pemberdayaan dan peran masing-masing stakeholder ditentukan secara jelas dengan panduan perencanaan pemberdayaan dengan melibatkan stakeholder yang ada yaitu pemerintah, masyarakat Desa Pakraman Tegallalang dan masyarakat petani pemilik lahan (masyarakat Desa Kedisan) dengan penyatuan visi dan misi melalui kemitraan untuk menjaga keberlanjutan daya tarik wisata itu sendiri. Perlu dibentuk sebuah manajemen untuk memungut donasi dari wisatawan yang dilakukan oleh petani pemilik lahan.

Mengingat selama ini wisatawan yang berkunjung di daya tarik wisata Ceking selain membayar tiket masuk juga banyak terdapat pungutan donasi yang dipungut oleh petani yang berbeda. Hal ini tentu membuat wisatawan merasa kurang nyaman ketika melakukan trekking di areal persawahan Ceking. Apalagi para petani tersebut masih memiliki hubungan keluarga, sehingga disarankan untuk memungut donasi hanya satu kali saja untuk selanjutnya hasil dari donasi tersebut dibagi-bagikan ke petani pemilik lahan yang lain. Dalam pengelolaan dan pengembangan daya tarik wisata Ceking ke depannya hendaknya juga melibatkan masyarakat Desa Kedisan sebagai sebuah komunitas mengingat sebagian daya tarik secara administrasi berada di wilayah Desa Kedisan.

\section{Ucapan Terimakasih}

Penulis menyampaikan ucapan terima kasih kepada Prof. Dr. I Wayan Ardika, M.A. dan Dr. Ir. I Made Adhika, MSP., sebagai Pembimbing I dan Pembimbing II dalam penelitian dan penulisan tesis ketika menempuh 
program di Prodi S2 Kajian Pariwisata, Universitas Udayana. Ucapan terimakasih juga disampaikan kepada Prof. Dr. I Nyoman Darma Putra, M.Litt. sebagai Ketua Program Studi S2 Kajian Pariwisata dan Dr. Ir Syamsul Alam Paturusi, MSP sebagai Sekretaris Program S2 Kajian Pariwisata atas kesempatan dan bimbingan yang diberikan selama mengikuti perkuliahan dan telah memberikan masukan untuk menyempurnakan artikel ini. Ucapan terimakasih juga disampaikan kepada seluruh pihak yang telah membantu dan memberikan kepercayaan untuk menyelesaikan penelitian ini tepat pada waktunya.

\section{Daftar Pustaka}

Cohen, John and Uphoff, Norman T. 1977. Rural Development Participation: Concept and Measures for Project Design-Implementation and Evaluation. New York: Cornell University Press.

Korten, David C. 1986. Community Management: Asian Experince and Perspective. Connecticut: Kumarian Press.

Kusmayadi dan Endar Sugiarto. 2000. Metodelogi Penelitian dalam Bidang Kepariwisataan. Jakarta: Gramedia Pustaka utama.

Mikkelsen, B. 2003. Metode Penelitian Partisipatoris dan Upaya-upaya Pemberdayaan. Jakarta: Yayasan Obor Indonesia.

Moeljarto, T. 1993. Politik Pembangunan - sebuah Analisis Konsep, Arah dan Strategi. Yogyakarta: PT Tiara Wacana.

Pitana, I Gde. 1999a. A Community Management dalam Pembangunan Pariwisata (Majalah Ilmiah Pariwisata - Analisis Pariwisata Program Studi Pariwisata Universitas Udayana Volume 2 Nomor 2 Tahun 1999 Hal. 75-77).

Pitana, I Gde. Pemberdayaan \& Hiperdemokrasi dalam Pembangunan Pariwisata. Penyunting Darma Putra, I Nyoman dan Pitana, I Gde. 2011. Pemberdayaan \& Hiperdemokrasi dalam Pembangunan Pariwisata. Denpasar: Pustaka Larasan.

\section{Profil Penulis}

Fatrisia Yulianie, SST.Par menyelesaikan studi master di Program Studi Magister Kajian Pariwisata Universitas Udayana. Sebelum memasuki program master Kajian Pariwisata, menyelesaikan program D4 Pariwisata di Universitas Udayana pada tahun 2007 dengan gelar Sarjana Sains Terapan Pariwisata (SST.Par). Pada tahun 2013 melanjutkan Program Magister Kajian Pariwisata di Universitas Udayana dan tamat tahun 2015. 